\title{
Low serum albumin and the acute phase response predict low serum selenium in HIV-I infected women
}

\author{
Paul K Drain ${ }^{1}$, Jared M Baeten ${ }^{2}$, Julie Overbaugh7, Mark H Wener ${ }^{2,3,4}$, \\ Daniel D Bankson ${ }^{3,4,6}$, Ludo Lavreys ${ }^{5,9}$, Kishorchandra Mandaliya ${ }^{8}$, \\ Jeckoniah O Ndinya-Achola ${ }^{9}$ and R Scott McClelland*2,5,9
}

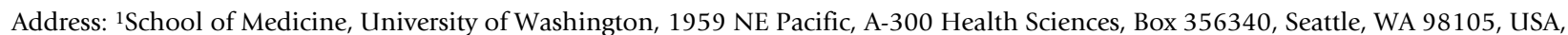
${ }^{2}$ Department of Medicine, University of Washington, 1959 NE Pacific, A-300 Health Sciences, Box 356340, Seattle, WA 98105, USA, ${ }^{3}$ Department of Laboratory Medicine, University of Washington, 1959 NE Pacific, A-300 Health Sciences, Box 356340, Seattle, WA 98105, USA, ${ }^{4}$ Clinical Nutrition Research Unit Laboratory Core, University of Washington, 1959 NE Pacific, A-300 Health Sciences, Box 356340, Seattle, WA 98105, USA, ${ }^{5}$ Department of Epidemiology, University of Washington, 1959 NE Pacific, A-300 Health Sciences, Box 356340, Seattle, WA 98105, USA, ${ }^{6}$ Veterans Affairs Puget Sound Health Care System, Seattle, USA, ${ }^{7}$ Divisions of Human Biology and Public Health Sciences, Fred Hutchinson Cancer Research Center, Seattle, USA, ${ }^{8}$ Department of Pathology, Coast Provincial General Hospital, Mombasa, Kenya and ${ }^{9}$ Department of Medical Microbiology, University of Nairobi, Nairobi, Kenya

Email: Paul K Drain - pkdrain@u.washington.edu; Jared M Baeten - jbaeten@partners.org; Julie Overbaugh - joverbau@fhcrc.org; Mark H Wener - wener@u.washington.edu; Daniel D Bankson - daniel.bankson@med.va.gov; Ludo Lavreys - llavreys@africaonline.co.ke; Kishorchandra Mandaliya - kishor@ikenya.com; Jeckoniah O Ndinya-Achola - ndinya-achola@kaviuon.org; R

Scott McClelland* - mcclell@africoonline.co.ke

* Corresponding author
\end{abstract}

Published: 19 May 2006

BMC Infectious Diseases 2006, 6:85 doi:10.1 |86/147/-2334-6-85
Received: 28 November 2005

Accepted: 19 May 2006

This article is available from: http://www.biomedcentral.com/I47/-2334/6/85

(C) 2006 Drain et al; licensee BioMed Central Ltd.

This is an Open Access article distributed under the terms of the Creative Commons Attribution License (http://creativecommons.org/licenses/by/2.0), which permits unrestricted use, distribution, and reproduction in any medium, provided the original work is properly cited.

\begin{abstract}
Background: Low serum selenium has been associated with lower CD4 counts and greater mortality among HIV-I-seropositive individuals, but most studies have not controlled for serum albumin and the presence of an acute phase response.

Methods: A cross-sectional study was conducted to evaluate relationships between serum selenium concentrations and CD4 count, plasma viral load, serum albumin, and acute phase response markers among $400 \mathrm{HIV}$-I-seropositive women.

Results: In univariate analyses, lower CD4 count, higher plasma viral load, lower albumin, and the presence of an acute phase response were each significantly associated with lower serum selenium concentrations. In multivariate analyses including all four of these covariates, only albumin remained significantly associated with serum selenium. For each $0.1 \mathrm{~g} / \mathrm{dl}$ increase in serum albumin, serum selenium increased by $0.8 \mu \mathrm{g} / \mathrm{l}(\mathrm{p}<0.00 \mathrm{I})$. Women with an acute phase response also had lower serum selenium (by $5.6 \mu \mathrm{g} / \mathrm{l}, \mathrm{p}=0.06$ ).

Conclusion: Serum selenium was independently associated with serum albumin, but not with CD4 count or plasma viral load, in HIV-I-seropositive women. Our findings suggest that associations between lower serum selenium, lower CD4 count, and higher plasma viral load may be related to the frequent occurrence of low serum albumin and the acute phase response among individuals with more advanced HIV-I infection.
\end{abstract}




\section{Background}

Nutritional deficiencies have long been recognized as an important problem among HIV-1-seropositive individuals, particularly in resource-limited settings [1]. Micronutrient deficiencies have been associated with more rapid HIV-disease progression and higher HIV-1 related mortality $[2,3]$. In some studies, micronutrient supplementation has delayed time to AIDS and improved survival, suggesting that supplementation could offer a simple and relatively inexpensive strategy to slow HIV-1 progression $[4,5]$.

Selenium is an antioxidant micronutrient that is an essential element of selenoproteins, including selenoprotein $P$ and glutathione peroxidase. Among HIV-1-seropositive individuals, lower serum selenium concentrations have been associated with lower CD4 counts, more advanced HIV-1 disease, and greater HIV-1 related mortality [6-10]. However, most studies have not controlled for low serum albumin, which binds non-specifically to selenium in serum, or for the presence of an acute phase response, which alters hepatic production of albumin and other serum proteins $[11,12]$. We sought to determine whether serum selenium was independently associated with CD4 count or plasma viral load after adjusting for serum albumin and the presence of an acute phase response.

\section{Methods \\ Study design}

A cross-sectional study was conducted using baseline data from 400 HIV-1-seropositive women enrolled in a randomized trial of micronutrient supplementation [13]. Data were collected between September 1998 and June 2000 at Coast Provincial General Hospital in Mombasa, Kenya. Women between 18 and 45 years old were enrolled if they were not currently or recently (last 3 months) pregnant, taking vitamin supplements, or using oral contraceptives. The enrollment criteria were based on the parent trial of micronutrient supplementation [13]. All participants were antiretroviral naïve. The protocol was approved by the institutional review boards of the University of Nairobi and the University of Washington, and all women provided written informed consent.

Detailed procedures and sample collection techniques have been previously described []. In brief, women were interviewed regarding demographic, sexual, and medical characteristics using a standardized questionnaire. A physical examination was performed. Blood was collected for lymphocyte subset analysis, quantitation of plasma HIV1 RNA, and nutritional assays.

\section{Laboratory methods}

Serum samples were protected from light, separated within 4 hours of collection, and stored at $-70^{\circ} \mathrm{C}$. Serolog- ical testing for HIV-1 was performed using an ELISA (Detect HIV 1/2, BioChem Immunosystems, Montreal, Canada), and confirmed with a second ELISA (Recombigen, Cambridge Biotech, Worcester, USA). Absolute CD4 counts were determined using a semiautomated system (Zymmune CD4/CD8 Cell Monitoring Kit, Bartels Inc., Issaquah, USA), which had a lower quantitation limit of 25 cells/ $\mu$ l. The quantity of HIV-1 RNA in plasma was determined using the Gen-Probe HIV-1 viral load assay (Gen-Probe Incorporated, San Diego, USA). The lower limit of quantification for the assay was 3 copies/ reaction, which was equivalent to 12 copies $/ \mathrm{ml}$ for the plasma volumes tested [14]. Serum selenium was quantified using graphite furnace atomic absorption spectrophotometry [15]. Serum albumin, C-reactive protein (CRP), and $\alpha_{1}$-acid glycoprotein (AGP) were determined by nephelometry (Dade Behring, Marburg, Germany).

\section{Statistical analysis}

Data were analyzed using SPSS 12.0 (SPSS Inc., Chicago, USA). Low serum selenium was defined as a serum level $\leq$ $85 \mu \mathrm{g} / \mathrm{l}[16]$, a threshold that has been associated with adverse outcomes in HIV-1 infection [7,8]. An acute phase response was considered to be present if a participant had $\mathrm{CRP} \geq 1 \mathrm{mg} / \mathrm{dl}$ [12] or AGP $\geq 100 \mathrm{mg} / \mathrm{dl}$ [17]. Univariate comparisons were performed using chi-square tests for dichotomous outcomes and t-tests for continuous outcomes. Multivariate comparisons were conducted using logistic and linear regression. Plasma HIV-1 RNA levels were $\log _{10}$ transformed to approximate a normal distribution.

\section{Results \\ Study population}

Baseline characteristics of this study population have been described [13]. In brief, participants had a mean age of 29 years [standard deviation $(S D) \pm 6$ ] with 7 years $(S D \pm 4)$ of education. Participants were generally of low socioeconomic status, as evidenced by only 35 (9\%) having a toilet in the home. Two hundred twenty (55\%) participants were married. The women had a mean of 3 children (SD $\pm 2)$, and $73(18 \%)$ were using injectable progesterone contraception (depot medroxyprogesterone acetate). The mean serum selenium concentration was $100 \mu \mathrm{g} / \mathrm{l}(\mathrm{SD} \pm$ 26).

Comparison of women with low vs. normal serum selenium Women with low serum selenium had more advanced immunosuppression, higher plasma viral loads, lower albumin, more frequent symptoms and signs of HIV-1 infection, and were more likely to have an acute phase response compared to women with normal serum selenium (Table 1). In a multivariate model including CD4 count, plasma viral load, albumin, and the acute phase response, only serum albumin concentration and the 
Table I: Comparison of HIV-I-Seropositive Women with Low $(\leq 85 \mu \mathrm{g} / \mathrm{I})$ versus Normal $(>85 \mu \mathrm{g} / \mathrm{I})$ Serum Selenium Concentrations.

\begin{tabular}{|c|c|c|c|c|c|}
\hline & \multicolumn{3}{|c|}{ Mean $( \pm$ SD) or Number (\%) } & \multicolumn{2}{|c|}{ Multivariate Logistic Regression' } \\
\hline & $\begin{array}{l}\text { Low serum selenium } \\
\qquad(\mathrm{n}=104)\end{array}$ & $\begin{array}{l}\text { Normal serum selenium } \\
\qquad(\mathrm{n}=296)\end{array}$ & $\mathrm{p}$-value ${ }^{2}$ & Adjusted Odds Ratio (95\% Cl) & $\mathrm{p}$-value \\
\hline CD4 count (cells/ $\mu \mathrm{l})$ & $216( \pm 182)$ & $300( \pm 210)$ & $<0.001$ & $0.90(0.77,1.06)^{3}$ & 0.2 \\
\hline Plasma HIV-I RNA ( $\log _{10}$ of copies/ml) & $5.6( \pm 0.9)$ & $5.3( \pm 1.0)$ & 0.01 & $0.84(0.61,1.17)$ & 0.3 \\
\hline Serum albumin $(g / d l)$ & $2.86( \pm 0.75)$ & $3.34( \pm 0.68)$ & $<0.001$ & $0.93(0.90,0.97)$ & $<0.001$ \\
\hline Acute phase response ${ }^{4}$ & $73(70 \%)$ & $129(44 \%)$ & $<0.001$ & $1.83(1.05,3.18)$ & 0.03 \\
\hline HIV-I symptoms ${ }^{5}$ & $83(80 \%)$ & 198 (67\%) & 0.008 & - & - \\
\hline HIV-I signs ${ }^{6}$ & $34(33 \%)$ & 57 (19\%) & 0.01 & - & - \\
\hline Body mass index $\left(\mathrm{kg} / \mathrm{m}^{2}\right)$ & $21.5( \pm 3.5)$ & $22.3( \pm 4.7)$ & 0.08 & - & - \\
\hline
\end{tabular}

$\mathrm{SD}$ - standard deviation; $\mathrm{Cl}$ - confidence interval

I CD4 count, plasma HIV-I RNA, serum albumin were modeled as continuous variables, and the acute phase response was modeled as a dichotomous variable.

2 Calculated by using t-tests for continuous variables and $\chi^{2}$ tests for dichotomous variables.

3 Odds ratio is per $100 \mathrm{CD} 4$ cells/ $\mu \mathrm{l}$ increase.

${ }^{4}$ The presence of C-reactive protein $\geq 1 \mathrm{mg} / \mathrm{dl}$ and/or $\alpha_{1}$-acid glycoprotein $\geq 100 \mathrm{mg} / \mathrm{dl}$.

${ }^{5}$ Defined as fever for $\geq I$ month, diarrhea for $\geq I$ month, cough for $\geq I$ month, unintended weight loss of $\geq 5 \mathrm{~kg}$ during previous year, or itching skin rash during previous year.

${ }^{6}$ Defined as the presence of oral thrush, oral hairy leukoplakia, oral ulcer, maculopapular rash, or Kaposi's sarcoma.

presence of an acute phase response remained significantly associated with low serum selenium. When included in the multivariate model, signs and symptoms of HIV-1 and body mass index were not independently associated with serum selenium and their inclusion did not significantly affect the association between selenium and albumin or the acute phase response, so these covariates were not included in the final multivariate model.

\section{Correlates of serum selenium}

In univariate analyses, higher CD4 count and higher serum albumin concentrations were associated with higher serum selenium concentrations, while higher plasma viral load, the presence of an acute phase response, and symptoms or signs of HIV-1 disease were associated with lower selenium concentrations (Table 2).
In a multivariate model including $\mathrm{CD} 4$ count, plasma viral load, albumin, and the acute phase response, only albumin was significantly associated with serum selenium. Each $0.1 \mathrm{~g} / \mathrm{dl}$ increase in serum albumin was associated with an $0.8 \mu \mathrm{g} / \mathrm{l}$ [95\% confidence interval (CI) $0.4-$ 1.2] increase in serum selenium. Women with an acute phase response had lower serum selenium concentrations than women without an acute phase response, although this association did not reach statistical significance. Signs or symptoms of HIV-1 and body mass index were not associated with serum selenium and did not substantially affect the associations between selenium and albumin or the acute phase response results, so these variables were not included in the final multivariate model. In separate multivariate models evaluating CRP and AGP as continuous covariates, neither of these inflammatory markers was

Table 2: Correlates of Serum Selenium Concentration ( $\mu \mathrm{g} / \mathrm{I})$ among 400 HIV-I-Seropositive Women.

\begin{tabular}{|c|c|c|c|c|}
\hline & \multicolumn{2}{|c|}{ Univariate Linear Regression } & \multicolumn{2}{|c|}{ Multivariate Linear Regression } \\
\hline & Coefficient $(95 \% \mathrm{Cl})$ & p-value & Coefficient $(95 \% \mathrm{Cl})$ & p-value \\
\hline CD4 count (per 100 cells $/ \mu 1$ increase) & I.8 $(0.6,3.0)$ & 0.004 & $0.2(-1.3,1.7)$ & 0.8 \\
\hline Plasma HIV-I RNA (per I log 10 copies/ml increase) & $-3.5(-6.1,-0.8)$ & 0.01 & $0.6(-2.7,3.8)$ & 0.7 \\
\hline Serum albumin (per $0.1 \mathrm{~g} / \mathrm{dl}$ increase) & $1.0(0.7,1.3)$ & $<0.001$ & $0.8(0.4,1.2)$ & $<0.001$ \\
\hline Acute phase responsel & $-10.8(-15.8,-6.0)$ & $<0.001$ & $-5.4(-10.9,0.1)$ & 0.06 \\
\hline HIV-I symptoms ${ }^{2}$ & $-9.5(-14.9,-4.0)$ & 0.001 & - & - \\
\hline HIV-I signs ${ }^{3}$ & $-7.0(-13.0,-1.1)$ & 0.02 & - & - \\
\hline Body mass index $\left(\mathrm{kg} / \mathrm{m}^{2}\right)$ & $0.17(-0.4,0.7)$ & 0.5 & - & - \\
\hline
\end{tabular}

$\mathrm{Cl}$ - confidence interval

IThe presence of C-reactive protein $\geq 1 \mathrm{mg} / \mathrm{dl}$ and/or $\alpha_{1}$-acid glycoprotein $\geq 100 \mathrm{mg} / \mathrm{dl}$.

2 Defined as fever for $\geq I$ month, diarrhea for $\geq I$ month, cough for $\geq I$ month, unintended weight loss of $\geq 5 \mathrm{~kg}$ during previous year, or itching skin rash during previous year.

${ }^{3}$ Defined as the presence of oral thrush, oral hairy leukoplakia, oral ulcer, maculopapular rash, or Kaposi's sarcoma. 
independently associated with serum selenium (data not shown).

\section{Discussion}

In this cross-sectional study of HIV-1-seropositive women, low serum selenium was independently associated with serum albumin and with the acute phase response, but not with CD4 count or plasma viral load. Further prospective studies may help determine whether associations between low serum selenium and low CD4 count $[6,9]$ and more advanced HIV-1 disease [10] could be related to the frequent occurrence of hypoalbuminemia and the acute phase response in people with advanced HIV-1 infection.

Several ingested forms of selenium, including selenomethionine, bind non-specifically to albumin for transport to the liver $[11,18-21]$. The liver converts these compounds into selenocysteine, which is used to form various selenoproteins. In total, approximately $55 \%$ of selenium in human serum exists in selenoprotein $P$, another 17$32 \%$ exists bound to albumin, mostly in the form of selenomethionine, and only $10 \%$ of serum selenium is not protein bound $[11,18,21]$. Since low serum albumin has been independently associated with faster HIV-1 disease progression and higher mortality, low serum selenium may simply reflect a decline in serum albumin among people with more active or advanced HIV-1 disease $[6,23]$.

The presence of an acute phase response is typically associated with a decrease of serum albumin and other plasma proteins [12]. Among HIV-1-seropositive individuals, the acute phase response has also been associated with low serum selenium and with HIV-1 disease progression and mortality $[6,24]$. One study found that CRP predicts mortality in HIV-1-infected women independent of serum albumin [25]. Our results suggest that the observed univariate associations between serum selenium and the acute phase response may have been due, at least in part, to decreased hepatic production of albumin and other plasma proteins in HIV-1-seropositive individuals with an acute phase response $[18,22]$. There may also be a redistribution of selenium from serum and liver to muscle tissue during an acute phase response [22].

Our study builds on previous analyses by examining the relationship between serum selenium concentrations, CD4 count, and plasma HIV-1 viral load in a large cohort of untreated HIV-1-seropositive adults. The size of this study enhanced our ability to conduct detailed multivariate analyses, which demonstrate the lack of a significant independent association between selenium and CD4 cell count or plasma viral load.
We have previously published the results of the micronutrient supplementation trial in which these women received six weeks of either a supplement containing $B$ vitamins, vitamin $\mathrm{C}$, vitamin $\mathrm{E}$, and selenium or an identical placebo [13]. Following supplementation, women who received the supplement had slightly higher CD4 counts compared to those who received placebo, an effect that was also observed in a trial of an otherwise identical supplement that did not contain selenium [5]. It is not possible to disentangle the independent effects of selenium from the known effects of those other micronutrients that were provided in the same supplement. Thus, we were unable to use those longitudinal data to evaluate the associations between selenium supplementation and albumin, CD4 count, and plasma viral load.

The findings presented here should be interpreted in the context of the limitations of this study. Although crosssectional studies are useful to define associations, it is not possible to infer with certainty that low albumin or the acute phase response were the cause of low measured serum selenium, although this relationship seems plausible because a large proportion of serum selenium is protein bound $[18,22]$. Regardless of the mechanism, the confounding bias demonstrated by our analyses was strong enough to nullify highly significant univariate associations between serum selenium and CD4 count and plasma viral load. However, these data cannot rule out the possibility that low serum selenium or a low antioxidant status was the cause of low serum albumin. Furthermore, because hypoalbuminemia may influence the relationship between serum selenium and total body selenium status, the measured serum selenium may not accurately reflect total body selenium in advanced HIV-1 infection. Data on dietary selenium intake were not collected in this population. Finally, because this study included only women, these results may not be generalizable to HIV-1seropositive men.

The finding that serum selenium is not independently associated with CD4 count or plasma viral load may help to explain the results of small randomized and non-randomized trials of selenium supplementation among HIV-1seropositive individuals. While one study found an increase in CD4/CD8 ratio after 12 weeks [26], none have demonstrated significant effects on the absolute CD4 cell count or plasma viral load $[10,26,27]$. However, a beneficial effect of selenium supplementation that is independent of CD4 count and plasma viral load is possible. In one randomized trial, selenium supplementation decreased hospital admissions due to infections among HIV-1 infected adults [28]. The trial did not report changes in biological markers of HIV-1 disease progression or the effect on HIV-1-related mortality. 


\section{Conclusion}

The results of this investigation demonstrate that serum selenium was not independently associated with CD4 count or plasma viral load among HIV-1-seropositive women. These findings indicate that studies assessing the impact of selenium on HIV-1 surrogate markers, such as CD4 cell count and plasma viral load, need to control for serum albumin levels and the presence of an acute phase response.

\section{Abbreviations}

AGP $-\alpha_{1}$-acid glycoprotein

CI - Confidence Interval

CRP - C-reactive protein

SD - Standard Deviation

\section{Competing interests}

The author(s) declare that they have no competing interests.

\section{Authors' contributions}

PKD, JMB, KM, JON, and RSM designed the study. LL, $\mathrm{JMB}, \mathrm{KM}$ and RSM collected data and provided study oversight. PKD and RSM analyzed data. PKD, JMB, JO, MHW, DDB, and RSM interpreted the results. PKD and RSM primarily wrote the manuscript. JMB, JO, MHW, DDH provided valuable insight for revising the manuscript. All authors read and approved the final manuscript.

\section{Acknowledgements}

This research was supported by National Institutes of Health grants Al43844 and Al39996, and University of Washington Clinical Nutrition Research Unit grant DK35816. JM Baeten was supported by the Fogarty International Center (FIC) grant D43-TW00007. RS McClelland was supported by FIC D43-TW00007 and by K23-AI52480. PK Drain was supported by the David E. Rogers Fellowship of The New York Academy of Medicine.

The authors wish to acknowledge the excellent work and valuable contributions made to this study by our clinic (Mary Wamugunda, Virginia Njuki, and Florence Murigi) and laboratory staff (Bhavna Chohan, Khamis Mwinyikai, Amina Abdalla, Gladwell Maina, Sandra Emery, and Dana Panteleeff). Del Landicho provided assistance with nutritional testing performed at the University of Washington's Clinical Nutrition Research Unit. We thank

Coast Provincial General Hospital for allowing us to use their clinical facilities. Finally, we would like to express our gratitude to the women who participated in this study, without whose time and effort this research would not have been possible.

\section{References}

I. Beach RS, Mantero-Atienza E, Shor-Posner G, Javier J], Szapocznik J, Morgan R, Sauberlich HE, Cornwell PE, Eisdorfer C, Baum MK: Specific nutrient abnormalities in asymptomatic HIV-I infection. AIDS 1992, 6:70I-708.

2. Semba RD, Graham NM, Caiaffa WT, Margolick JB, Clement L, Vlahov $D$ : Increased mortality associated with vitamin A deficiency during human immunodeficiency virus type I infection. Arch Intern Med 1993, I53:2149-2I54.

3. Tang AM, Graham NM, Semba RD, Saah AJ: Association between serum vitamin $A$ and $E$ levels and HIV-I disease progression. AIDS 1997, I I:613-620.

4. Jiamton S, Pepin J, Suttent R, Filteau S, Mahakkanukrauh B, Hanshaoworakul W, Chaisilwattana P, Suthipinittharm P, Shetty P, Jaffar S: A randomized trial of the impact of multiple micronutrient supplementation on mortality among HIV-infected individuals living in Bangkok. AIDS 2003, 17:246I-2469.

5. Fawzi WW, Msamanga GI, Spiegelman D, Wei R, Kapiga S, Villamor E, Mwakagile D, Mugusi F, Hertzmark E, Essex M, Hunter DJ: A randomized trial of multivitamin supplements and HIV disease progression and mortality. N Engl J Med 2004, 35 I:23-32.

6. Look MP, Rockstroch JK, Rao GS, Kreuzer KA, Spengler U, Sauerbruch $T$ : Serum selenium versus lymphocyte subsets and markers of disease progression and inflammatory response in human immunodeficiency virus-infection. Biol Trace Elem Res 1997, 56:31-4I.

7. Campa A, Shor-Posner G, Indacochea F, Zhang G, Lai H, Asthana D, Scott GB, Baum MK: Mortality risk in selenium-deficient HIVpositive children. J Acquir Immune Defic Syndr 1999, 20:508-5 I3.

8. Baum MK, Shor-Posner G, Lai S, Zhang G, Lai H, Fletcher MA, Sauberlich H, Page JB: High risk of HIV-related mortality is associated with selenium deficiency. J Acquir Immune Defic Syndr Hum Retrovirol 1997, I 5:370-374.

9. Kupka R, Msamanga GI, Spiegelman D, Morris S, Mugusi F, Hunter DJ, Fawzi WW: Selenium status is associated with accelerated HIV disease progression among HIV-I-infected pregnant women in Tanzania. J Nutr 2004, 134:2556-2560.

10. Cirelli A, Ciardi M, De Simone C, Sorice F, Giordano R, Ciaralli L, Constantini S: Serum selenium concentration and disease progress in patients with HIV infection. Clin Biochem I99I, 24:2|I-2|4.

II. Deagan JT, Butler JA, Zachara A, Whanger PD: Determination of the distribution of selenium between glutathione peroxidase, selenoprotein $\mathbf{P}$, and albumin in plasma. Analytical Biochem 1993, 208: 176-181.

12. Gabay C, Kushner I: Acute-phase proteins and other systemic responses to inflammation. N Eng J Med 1999, 340:448-454.

13. McClelland RS, Baeten JM, Overbaugh J, Richardson BA, Mandaliya K, Emery S, Lavreys L, Ndinya-Achola JO, Bankson DD, Bwayo J], Kreiss $\mathrm{JK}$ : Multivitamin supplementation increases genital tract shedding of HIV-I in women: Results of a randomized trial. J Acquir Immune Defic Syndr 2004, 37: I657-1663.

14. Panteleeff DD, Emery S, Richardson BA, Rousseau C, Benki S, Bodrug $S$, Kreiss JK, Overbaugh J: Validation of performance of the GenProbe human immunodeficiency virus type I viral load assay with genital swabs and breast milk samples. J Clin Microbiol 2002, 40:3929-3937.

15. Ericson SP, McHalsky ML, Rabinow BE, Kronholm KG, Arceo CS, Weltzer JA, Ayd SW: Sampling and analysis techniques for monitoring serum for trace elements. Clin Chem 1986, 32:1350-1356.

16. Hardy G, Hardy I: Selenium: The Se-XY nutraceutical. Nutrition 2004, 20:590-593.

17. Thurnham DI, McCabe GP, Northrop-Clewes, Nestel P: Effects of subclinical infection on plasma retinol concentrations and assessment of prevalence of vitamin A deficiency: meta-analysis. Lancet 2003, 362:2052-2058.

18. Harrison I, Littlejohn D, Fell GS: Distribution of selenium in human blood plasma and serum. Analyst 1996, 121:189-194.

19. Shiobara Y, Suzuki KT: Binding of selenium (administered as selenite) to albumin after efflux from red blood cells. / Chromatogr B Biomed Sci Appl 1998, 7 I 0:49-56.

20. Burk RF, Hill KE, Motley AK: Plasma selenium in specific and non-specific forms. Biofactors 200I, I4:107-II4.

21. Suzuki KT, Itoh M: Metabolism of selenite labelled with enriched stable isotope in the bloodstream. I Chromatogr $B$ Biomed Sci Appl 1997, 692: 15-22.

22. Maehira F, Luyo GA, Miyagi I, Oshiro M, Yamane N, Kuba M, Nakazato $Y$ : Alterations of serum selenium concentrations in the acute phase of pathological conditions. Clin Chim Acta 2002, 316:137-146.

23. Feldman JG, Gange SJ, Bacchetti P, Cohen M, Young M, Squires KE, Williams C, Goldwasser P, Anastos K: Serum albumin is a power- 
ful predictor of survival in HIV-I-infected women. J Acquir Immune Defic Syndr 2003, 33:66-73.

24. Baeten JM, McClelland RS, Richardson BA, Bankson DD, Lavreys L, Wener MH, Overbaugh J, Mandaliya K, Ndinya-Achola JO, Bwayo JJ, Kreiss JK: Vitamin A deficiency and the acute phase response among HIV-I-infected and -uninfected women in Kenya. J Acquir Immune Defic Syndr 2002, 3 I:243-249.

25. Feldman JG, Goldwasser P, Holman S, DeHovitz J, Minkoff H: Creactive protein is an independent predictor of mortality in women with HIV-I infection. J Acquir Immune Defic Syndr 2003, 32:210-2|4.

26. Look MP, Rockstroh JK, Rao GS, Barton S, Lemoch H, Kaiser R, Kupfer B, Sudhop T, Spengler U, Sauerbruch T: Sodium selenite and $\mathrm{N}$-acetylcysteine in antiretrovial-naive HIV-I-infected patients: a randomized, controlled pilot study. Euro J Clin Investigation 1998, 28:389-397.

27. Delmas-Beauvieux MC, Peuchant E, Couchouron A, Constans J, Sergeant C, Simonoff M, Pellegrin JL, Leng B, Conri C, Clerc M: The enzymatic antioxidant system in blood and glutathione status in human immunodeficiency virus (HIV)-infected patients: effects of supplementation with selenium or $\beta$-carotene. Am J Clin Nutr 1996, 64: I0I-I07.

28. Burbano X, Miguez-Burbano MJ, McCollister K, Zhang G, Rodriguez A, Ruiz P, Lecusay R, Shor-Posner G: Impact of a selenium chemoprevention clinical trial on hospital admissions of HIVinfected participants. HIV Clin Trials 2002, 3:483-49I.

\section{Pre-publication history}

The pre-publication history for this paper can be accessed here:

http://www.biomedcentral.com/1471-2334/6/85/prepub

\section{Publish with Biomed Central and every scientist can read your work free of charge}

"BioMed Central will be the most significant development for disseminating the results of biomedical research in our lifetime. "

Sir Paul Nurse, Cancer Research UK

Your research papers will be:

- available free of charge to the entire biomedical community

- peer reviewed and published immediately upon acceptance

- cited in PubMed and archived on PubMed Central

- yours - you keep the copyright 